\title{
論文・作品の発表の場におけるピアレビューに 関する倫理規程
}

序

日本建築学会は, 建築に関卞る学術・技術・芸術の進歩発展 を図るために，会員に対する発表の場の整備，拡立を行い，諭 文集，技術報告集，英文論文集，総合論文誌（これらを論文集 等と称し，そこに揭載される内容を論文と称する）および作品 選集の出版活動を推進してきた。

今後ともこれらの活動が適切に行われるためには，論文集等 へ論文の揭載を求めて投稿する著者, 作品選集へ作品の揭載を 求めて応募する設計者, 掲載の可否を審查する查読者・選考委 員，またそれらを編集・出版する委員会のそれぞれが，倫理的 な規準を満たして活動しなければならない。

倫理規程は，個々の論文と作品を，オリジナリティを有し優 れた水準が確保されたものとするために必要とされる。しかも その際に, 著者・設計者は他者の諸権利を侵害してはならない し, 查読者・選考委員は著者・設計者の諸権利を侵害してはな らない。

本会では既に1999年に「倫理綱領・行動規範」を制定・公表 している。本倫理規程はこの綱領・規範のもとに，論文・作品 の発表・揭載をより一層学会内・外から信頼されるものとす心゙ く，制定し公表するに至ったものである。

\section{1 章 論文集等 \\ 1 節 著者の義務}

\section{1 論文の要件}

投稿する論文は応募規程に示された諸条件を満たしたもの で，学術・技術あるいは芸術の進歩発展に資するに足る水準が 確保されたものでなければならない。また，研究が多くの者の 関与においてなされた一連のものである場合でも, 当該論文は, 著者が直接に関与した部分について一つの完成したものとして 取りまとめられていなければならない。

\section{2 共同著者}

共同著者とは, 当該論文の完成に意義ある貢献を果たし論文 内容に共同の責任を負える者全員であり，またその範囲に限ら れる。筆頭に名を揭げる主著者は, 論文への貢献が最も高いと 認められる者でなければならない。主著者には共同著者にその 完成稿を提示し投稿への同意を得ることが求められる。なお死 去した者であっても，これらの条件(同意の条件は必須とせず) のもとに共同著者となることができる。

1.3 十分な情報の提供

論文において著者は, 同じ分野を研究する者がその研究を再 現したり検証・評価しうるに足る情報を提供し, 論証の過程を 示さなければならない。また，既往論文等についての十分なレ ビューを行うとともに，引用する場合にはその引用元を示さな ければならない。

1.4 他者からの引用に際しての注意
著者は他者からの情報を引用するにあたって，それが読者に も入手可能であることを確認するとともに，他者がもつ著作権 の存在に留意しなければならない。

1.5 捏造の禁止

投稿原稿には捏造された情報が含まれてはならない。捏造と は故意に自己または他者のデー夕を改竄することである。

1.6 既往論文の批判的引用に関する注意

著者が既往論文に対し学術的根拠をもって批判的に引用・記 述寸ることは許されるが，誹謗はもちろんとして根拠不明のま まに批判することは許されない。

1.7 調查対象者・被験者の人権等の保護

著者は論文に先立つ研究において，調查等の对象となる市民 の人権等を侵害してはならず，また実験等に際しては被験者の 生命・健康・プライバシー抢よび尊㛜を守らなければならない。 1.8 商業的意図等の排除

明らかに商業的意図あるいは政治的，宗教的意図があると判 断される論文は不適切である。

1.9 他者の権利を侵害した場合の責任

論文の内容が他者の著作権を侵害した場合には，その責任は すべて著者にあって，本会はこれらに関し直接的な責任を負う ものではない。

\section{2 節 查読者の義務}

2.1 查読者の役割の自覚

論文揭載の可否を判断するに際して查読者の役割は極めて大 きく, その責任の重大性を自覚して査読期限を守り速やかに進 めなければならない。

\section{2 查読の辞退}

查読依頼を承諾することは会員として果たすべき義務である が, 查読者が著者や当該論文等との個人的な利害の関係, ある いは自己が専門とする分野との不整合等の事情で查読に相応し くないと判断した場合，また查読についての時間的余裕がない と判断した場合には, 速やかに相読を辞退しなければならない。 2.3 查読の客観性の確保

查読は建築学の進歩発展への有益性の観点から, 客観的かつ 論理的になされなければならず，個人的な考え方や，著者ある いは当該論文への好悪の感情をもととする客観的でない，また 論理的でない判断は厳に控えなければならない。

2.4 論文の有益性

有益性とは，建築学においてこれまで培われてきた学術・技 術・芸術的な蓄積をさらに高めることを意味する。ただし, 従 来獲得されてきた方向性と異なるものであっても, 当該論文に おいてその妥当性が証明され, あるいは妥当性が論争されるべ きと判断される場合においては，それを拒否することがあって はならない。 


\section{5 著者への配慮}

查読結果の記述は論理的であるとともに，著者に理解しうる 文章表現でなされなければならない。また査読に際しては, 著 者の人格や知的独立性に十分な敬意を払い，それらへの軽視を 疑わせるような記述は避けなければならない。

\section{6 守秘義務}

査読者は査読の依頼を受けた事実，また査読中の論文の全部 あるいは一部の内容を他者に漏らしてはならない。

2.7 自己のための利用禁止

查読者は当該論文が公刊されるまでは，その内容を自己のた めに利用してはならない。

\section{8 論文集委員会等への報知} 查読者は論文の内容が既に公刊された論文と同一であること を発見したり，同一である疑いがあると判断した場合には，速 やかに論文集委員会, 技術報告集委員会, 英文論文集委員会, 総合論文誌委員会（論文集委員会等と総称する）にそれを報知 しなければならない。また査読者は当該論文の中に捏造を発見 したり，その疑いがあると判断した場合には，速やかに論文集 委員会等にそれを報知しなければならない。

\section{3 節 論文集委員会等の義務}

3.1 諭文集委員会等の公正な運営

論文集委員会等は本規程の序に述べた目的を達成するため, 公正な運営に努めなければならない。

\section{2 查読者の選定}

論文集委員会等は当該論文の查読のために前もって定めた会 員よりなる候補者から，専門性を考慮して最も適切な查読者を 選定する。なおそれが必要と考えられる場合には，候補者以外 の会員および会員以外からも查読者を選定しうる。査読者の選 定は公正に行わなければならない。

\section{3 委員の守秘義務}

論文集委員会等の委員は查読に関する事項を他者に漏らして はならない。

\section{4 異議の申し立て}

論文集委員会等は不採用となった論文の著者から審査結果を 不服とする旨の申し出があった場合には，当該申し立ての妥当 性を速やかに検討しなければならない。検討結果は委員会名で 著者に通知するとともに，異議が妥当とされた場合には適切な 措置を取らなければならない。

\section{2 章 作品選集 \\ 1 節 設計者の義務}

1.1 作品の要件

応募する作品は募集要領に示された諸条件を満たしたもの で，学術・技術あるいは芸術の進歩発展に資するに足る水準が 確保されたものでなければならない。

1.2 共同設計者

共同設計者とは，当該作品の完成に意義ある貢献を果たし作 品内容に共同の責任を負える者全員であり，またその範囲に限 られる。筆頭に名を掲げる主設計者は, 作品への貢献が最も高
いと認められる者でなければならない。主設計者には共同設計 者にその完成作品を提示し応募への同意を得ることが求められ る。な拓死去した者であっても，これらの条件（同意の条件は 必須とせず）のもとに共同設計者となることができる。

1.3 他者の権利を侵害した場合の責任

作品の内容が他者の著作権等を侵害した場合には, その責任 はすべて設計者にあって，本会はこれらに関し直接的な責任を 負うものではない。

\section{2 節 選考委員の義務}

\section{1 選考委員の役割の自覚}

作品掲載の可否を判断するに際して選考委員の役割は極めて 大きく，その責任の重大性を自覚して選考作業を進めなければ ならない。

\section{2 選考の辞退}

選考委員は設計者との関係等において当該作品の選考に相応 しくないと自らが判断した場合，あるいは作品選集委員会によ り同様の判断がなされた場合，当該作品の選考を辞退しなけれ ばならない。

\section{3 守秘義務}

選考委員は選考結果が公表されるまでは，選考に関する事項 を他者に漏らしてはならない。

\section{3 節 作品選集委員会の義務}

3.1 作品選集委員会の公正な運営

作品選集委員会は本規程の序に述べた目的を達成するため, 公正な運㗬に努めなければならない。

付則この規程は2002年 7 月17日から施行する。

注 1 ：本規程の作成にあたっては,「Ethica1 Standards for Publication of ASCE Journals」を参考にした。

注 2 ：表題にあるピアレビュ一(peer review) とは専門を同じくする 会員による公正な評㑛のことである。 